Research article

\title{
NEUROLOGICAL DISEASES OF SMALL RUMINANTS IN GREECE: A RETROSPECTIVE STUDY IN 114 FLOCKS
}

\author{
POLIZOPOULOU S Zoe ${ }^{1}$, GIADINIS D Nektarios ${ }^{2 *}$, PAPAHRISTOU Andreas ${ }^{3}$, \\ PAPAIOANNOU Nikolaos ${ }^{4}$
}

\begin{abstract}
${ }^{1}$ Diagnostic Laboratory, School of Veterinary Medicine, Faculty of Health Sciences, Aristotle University of Thessaloniki, Greece; ${ }^{2}$ Clinic of Farm Animals, School of Veterinary Medicine, Faculty of Health Sciences, Aristotle University of Thessaloniki, Greece; ${ }^{3}$ Veterinary Service, Prefecture of Kilkis, Greece; ${ }^{4}$ Laboratory of Pathology, Faculty of Veterinary Medicine, Aristotle University of Thessaloniki, Greece
\end{abstract}

(Received 8 September 2015; Accepted 24 February 2016)

\begin{abstract}
Although neurological diseases comprise an important part of small ruminant internal medicine, the number of retrospective studies on their epidemiology conducted to date is limited. This study reports an extensive review of epidemiological data on the occurrence of neurological diseases in Greek sheep and goat herds. The survey was based on data retrieved from the records of the Farm Animal Clinic, School of Veterinary Medicine, A.U.TH from January 2006 to May 2011. Historical information, clinical and neurological examination, clinicopathological and (if available) pathological evaluation were the minimum data recorded in each case.

Diseases of the nervous system represented $37.9 \%$ and $19.2 \%$ of the total evaluated sheep and goat caseload, respectively. The most frequent neurological disorders diagnosed in sheep were chronic coenurosis and Scrapie, which accounted for $72 \%$ of cases, followed by less common conditions like ovine lentiviral encephalomyelitis (OLE), listeriosis and acute coenurosis. In goats the frequency of various types of neurological diseases was more evenly distributed, with listeriosis and polioencephalomalacia being the most commonly encountered problems.
\end{abstract}

Key words: Sheep, goats, neurological diseases, diagnosis

\section{INTRODUCTION}

Neurological diseases are common in small ruminant practice. Their importance is further emphasized by the fact that, apart from inflicted financial damage, some also have a zoonotic potential [1]. The diagnostic approach should be based on history analysis and a thorough clinical and neurological examination [2,3]. The latter is mandatory for identifying the location of lesions within the nervous system, which is

*Corresponding author: e-mail: ngiadini@vet.auth.gr 
the most important task of the diagnostic algorithm [3,4]. Analysis of the recorded data is important for the compilation of a differential list and planning of further actions. For example, laboratory testing for infectious diseases could aid in distinguishing primary neurological diseases from disorders (metabolic or toxic) exhibiting similar clinical manifestations [3,4]. A quick preliminary tentative diagnosis may allow early treatment with improved chances for a optimal result [2,5].

Specific neurological syndromes have been associated with certain diseases of small ruminants and include cerebral (chronic coenurosis, scrapie, ovine lentivirus encephalitis, enterotoxemia, polioencephalomalacia, metabolic encephalopathies), pontomedullary (listeriosis, chronic coenurosis), vestibular (listeriosis, chronic coenurosis, polioencephalomalacia) syndromes and spinal cord disease (chronic coenurosis, ovine lentivirus myelitis, spinal trauma) [3,5].

Small ruminants are an integral part of animal production in Greece, with sheep representing up to $38 \%$ and goats $19 \%$ of the total livestock population [6]. The initiative for carrying out this retrospective clinical study was the assessment of the frequency and type of neurological disorders in small ruminant farms located in northern and central Greece and provide a feedback to the practicing veterinarians of the same regions.

\section{MATERIALS AND METHODS}

Small ruminant neurological cases were selected after reviewing the medical records of the Farm Animal Clinic, School of Veterinary Medicine, A.U.TH. for a 5.5 year period (January 2006 to May 2011). Criteria for case selection included an informative history, a detailed clinical and neurological examination (always performed by the same examiners), along with an extensive clinicopathological (complete blood counts, serum biochemistry panel, urinalysis, cerebrospinal fluid analysis) and -where applicablepathological evaluation leading to an etiological diagnosis.

Most of the examined animals were transported by farm owners to the premises of the Farm Animal Clinic as representative cases of the disease that had been affecting the entire flock. In a smaller number of cases the mobile clinic staff had examined the affected animals on site.

Data retrieved from case files included farm location, number and species of reared animals, housing, feeding regimens, vaccination and anti-parasitic programs, history, presenting signs, previously administered treatments (if any), clinical and neurological examination findings, results of clinicopathological (including cerebrospinal fluid analysis and microbiology/serology reports, where applicable) and/or histopathological evaluation and outcome (Tables 1 and 2). 


\section{RESULTS}

From the case records studied, a neurological disorder was diagnosed in 93 sheep $(37.9 \%)$ and 21 goat $(19.2 \%)$ flocks, respectively. The analytical etiologic diagnoses are presented in Tables 1 (sheep) and 2 (goats). The most frequent diagnosis in sheep was chronic coenurosis $(43 / 93,46.2 \%)$ and Scrapie $(24 / 93,25.8 \%)$, followed by other less common disorders like ovine lentiviral encephalomyelitis (OLE), listeriosis (Fig. 1) and acute coenurosis (Table 1). In total, chronic coenurosis (Fig. 2, 3), Scrapie (Fig. 4) and OLE accounted for $78 \%$ of the neurologic conditions recorded. Alternatively, acute and chronic coenurosis comprised half of the caseload in this study. All chronic coenurosis cases presented signs of a focal encephalopathy with lesions localized in the cerebrum (28/43), brainstem (8/43) and cerebellum (7/43). Acute coenurosis cases typically were manifested as diffuse encephalopathies.

Table 1. Frequency of neurological diseases recorded in 93 sheep flocks

\begin{tabular}{|c|c|c|c|c|}
\hline $\begin{array}{l}\text { Neurological } \\
\text { disease }\end{array}$ & $\begin{array}{l}\text { Number* } \\
\text { of affected } \\
\text { flocks }\end{array}$ & $\begin{array}{l}\text { Number of } \\
\text { total affected } \\
\text { animals }\end{array}$ & $\begin{array}{c}\text { Percentage (\%) } \\
\text { of affected } \\
\text { flocks }\end{array}$ & $\begin{array}{l}\text { Diagnostic method(s) } \\
\text { used }\end{array}$ \\
\hline Chronic coenurosis & 43 & 91 & 45.7 & Intracranial surgery / PM \\
\hline Scrapie & 24 & 52 & 25.5 & $\begin{array}{l}\text { PM/histopathology / } \\
\text { immunohistopathology }\end{array}$ \\
\hline $\begin{array}{l}\text { Ovine Lentivirus } \\
\text { Encephalomyelitis } \\
\text { (OLE) }\end{array}$ & 9 & 34 & 9.6 & PM / histopathology \\
\hline Acute coenurosis & 4 & 13 & 4.3 & PM / histopathology \\
\hline Listeriosis & 4 & 4 & 4.3 & $\begin{array}{l}\text { Histopathology/ } \\
\text { Microbiology testing }\end{array}$ \\
\hline Rumen alkalosis & 3 & 4 & 3.2 & $\begin{array}{l}\text { Clinicopathological testing } \\
\text { (rumen } \mathrm{pH} \text { / histopathology } \\
\text { (no lesions detected) }\end{array}$ \\
\hline $\begin{array}{l}\text { Congenital CNS } \\
\text { malformations }\end{array}$ & 2 & 9 & 2.1 & $\mathrm{PM}$ \\
\hline Pregnancy toxaemia & 2 & 2 & 2.1 & $\begin{array}{l}\text { Clinicopathological } \\
\text { testing / PM }\end{array}$ \\
\hline Trauma & 2 & 2 & 2.1 & History / PM \\
\hline Enterotoxemia & 1 & 1 & 1.06 & Microbiological testing \\
\hline Meningoencephalitis & 1 & 2 & 1.06 & PM / microbiological testing \\
\hline Polioencephalomalacia & 1 & 3 & 1.06 & Therapeutic trial / PM \\
\hline Sarcocystosis & 1 & 2 & 1.06 & Histopathology \\
\hline Copper toxicosis & 1 & 2 & 1.06 & $\begin{array}{l}\text { Histopathology / toxicology } \\
\text { tests }\end{array}$ \\
\hline
\end{tabular}

* In five flocks the co-existence of more than 1 neurological disorder was recorded PM-post mortem examination 
Table 2. Frequency of neurological diseases recorded in 21 goat flocks

\begin{tabular}{|c|c|c|c|c|}
\hline $\begin{array}{l}\text { Neurological } \\
\text { disease }\end{array}$ & $\begin{array}{l}\text { Number* } \\
\text { of affected } \\
\text { flocks }\end{array}$ & $\begin{array}{l}\text { Number of } \\
\text { total affected } \\
\text { animals }\end{array}$ & $\begin{array}{l}\text { Percentage } \\
(\%) \text { of affected } \\
\text { flocks }\end{array}$ & $\begin{array}{l}\text { Diagnostic } \\
\text { method(s) used }\end{array}$ \\
\hline Listeriosis & 4 & 5 & 20 & $\begin{array}{l}\text { Histopathology/ } \\
\text { Microbiological testing }\end{array}$ \\
\hline Polioencephalomalacia & 3 & 5 & 15 & Therapeutic trial / PM \\
\hline Cerebral abscess & 2 & 2 & 10 & PM \\
\hline Enterotoxemia & 2 & & 10 & Microbiological testing \\
\hline $\begin{array}{l}\text { Presumed viral } \\
\text { encephalomyelitis }\end{array}$ & 2 & 2 & 10 & $\begin{array}{l}\text { Histopathology / } \\
\text { Immunohistopathology }\end{array}$ \\
\hline $\begin{array}{l}\text { Caprine arthritis- } \\
\text { encephalitis (CAE) }\end{array}$ & 2 & 5 & 10 & Histopathology / serology \\
\hline Rumen alkalosis & 1 & 3 & 5 & $\begin{array}{l}\text { Clinicopathological testing } \\
\text { (rumen } \mathrm{pH} \text { )/ histopathology } \\
\text { (no lesions detected) }\end{array}$ \\
\hline Chronic coenurosis & 1 & 2 & 5 & Intracranial surgery / PM \\
\hline Meningoencephalitis & 1 & 2 & 5 & PM / microbiological testing \\
\hline $\begin{array}{l}\text { Discospondylitis/ } \\
\text { spinal cord abscess }\end{array}$ & 1 & 1 & 5 & PM / microbiological testing \\
\hline Scrapie & 1 & 2 & 5 & $\begin{array}{l}\text { PM/histopathology / } \\
\text { immunohistopathology }\end{array}$ \\
\hline $\begin{array}{l}\text { Congenital cerebellar } \\
\text { malformations }\end{array}$ & 1 & 1 & 5 & $\mathrm{PM}$ \\
\hline
\end{tabular}

*In one flock the co-existence of more than 1 neurological disorder was recorded PM-post mortem examination
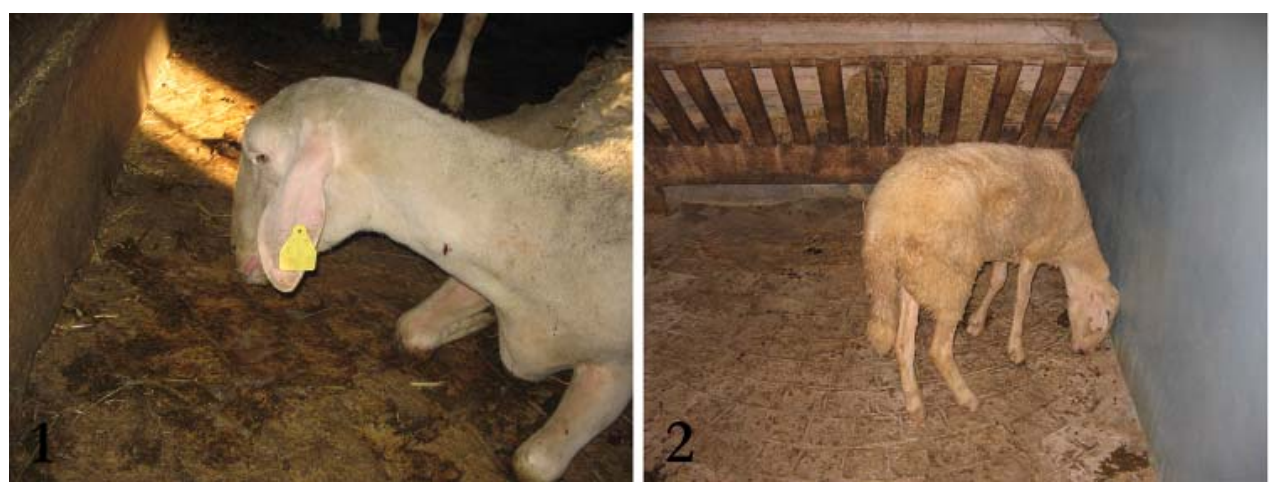

Figure 1. Sheep with listeriosis.

Figure 2. Lamb with chronic coenurosis.

In five sheep farms the concurrent existence of more than one neurological disorder was documented. In particular, chronic coenurosis coexisted with rumen alkalosis in two and with Scrapie in one farm, whereas Scrapie coexisted with OLE in another two farms. 

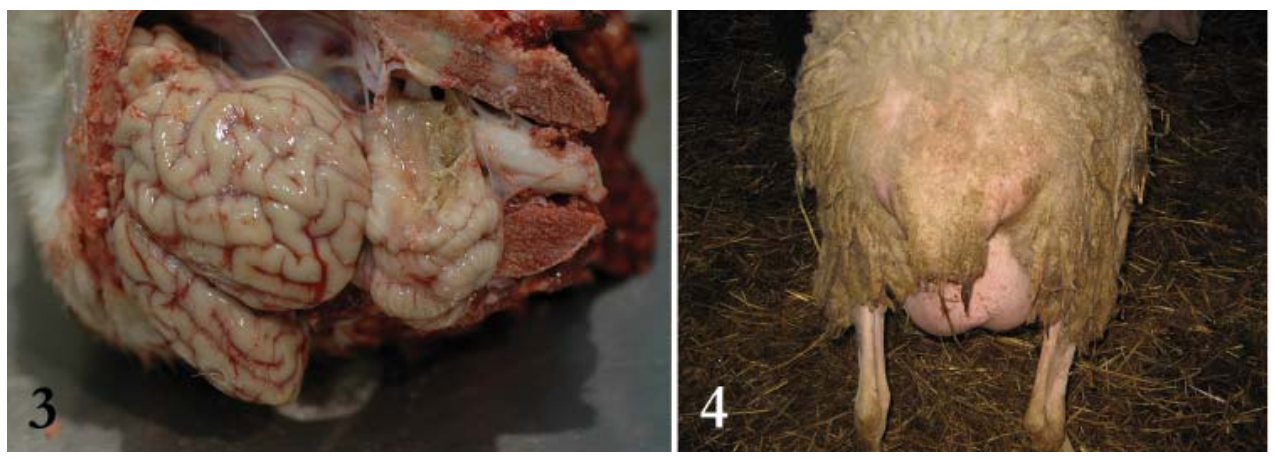

Figure 3. Coenurus cyst in the cerebellum of a lamb.

Figure 4. Sheep with pruritic skin lesions due to Scrapie.

In goats listeriosis and polioencephalomalacia (Fig. 5) were the most frequent diagnoses (Table 2). In two farms a definite etiologic diagnosis could not be established, but histopathologic brain lesions were compatible with viral encephalomyelitis. Nevertheless, a specific viral infection could not be documented. Concurrent existence of CAE (Fig. 6) and a cerebral abscess was recorded in one case.
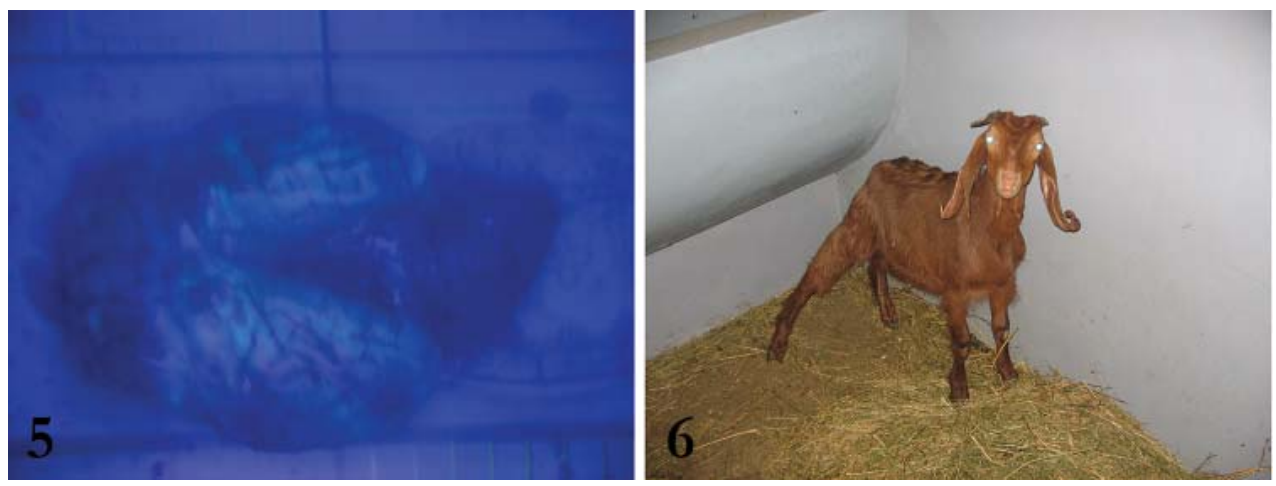

Figure 5. Brain from a sheep with polioenchephalomalacia under UV light.

Figure 6. Goat kid with cerebellar dysfunction due to CAE.

\section{DISCUSSION}

Common small ruminant neurological diseases, known to exist in Greece for several years, include infectious meningo-encephalomyelitis, Scrapie, chronic coenurosis, polioencephalomalacia, pregnancy toxemia, hypocalcemia and plant toxicoses [7]. Compiling their differential diagnosis list should be done while considering the signalment, history and anatomic localization of lesions or the patho-physiologic mechanisms of neurological disorders (congenital or hereditary, infectious, noninfectious). The latter may be more suitable in a clinical setting. However, definitive diagnosis can be established after paraclinical (laboratory) examinations and by therapeutic approach $[2,3,7]$. 
Not surprisingly, the frequency of neurological diseases in this study was relatively high and comparable to previous reports [1], in particular regarding sheep and compared to goats. The considerably lower incidence noted in goats could be attributed to the smaller number of animals reared in Greece which comprise 19\% of the total livestock population [7]. Another potential explanation could be the markedly higher incidence of chronic coenurosis and Scrapie in sheep. These disorders are encountered far less commonly in goats [7-11].

Chronic coenurosis was the most frequent diagnosis in sheep (Table 1), typically manifested as a slowly progressive focal encephalopathy [12-14], affecting mainly the cerebrum and less commonly the brainstem and cerebellum. Conversely, acute coenurosis, a clinical syndrome associated with the introduction of susceptible animals in heavily infested pastures or the administration of contaminated feedstuffs [15], was diagnosed far less frequently and only in four farms. Clinical signs of acute coenurosis differ from the chronic syndrome and are comparable to those of acute meningoencephalomyelitis or multi-focal encephalopathy. Its mortality rate is high, reaching up to $100 \%$ in some incidents. Common neurological signs in acute coenurosis included blindness, dementia, ataxia and dysmetria. Surviving animals often develop the chronic form of the disease with the formation of parasitic cysts after 3 to 6 months [16-18].

Conversely, coenurosis was recorded as an infrequent clinical problem in goats. This finding could be attributed to the special feeding habits of this species, along with the well documented differences in immunologic responses and host-parasite interactions. Regarding their feeding habits, goats are browser herbivores compared to sheep which are mainly grazers, thus being exposed to a significantly higher parasitic burden $[10,17]$. Clearly, farm management issues contribute to the extent of coenurosis in small ruminant farms. It is a common practice among Greek farm owners to neglect regular preventive anthelmintic treatment of sheepdogs and proper disposal of dead animals or animal organs avoiding their consumption by domestic and wild carnivores. This gradually leads to an increased parasitic burden of grazing fields and exposure of pasturing animals or contamination of harvested feedstuffs [18,19].

Scrapie was the second most frequently diagnosed neurologic disorder in sheep, but quite rarely in goats, as reported worldwide [10,20]. Both in sheep and goats this slowly progressive degenerative prion encephalopathy has two distinct histopathological variants, classical and atypical Scrapie. The latter is distinguished by lesions location mainly in the cerebellum and brainstem trigeminal nuclei [21].

The susceptibility of sheep to Scrapie is governed by genetic factors associated with gene polymorphism. Sheep populations in Greece are reported to be genetically susceptible to Scrapie and this may be one of the reasons for the high incidence of the disease in this study [22]. Therefore, the institution of an eradication programme focused on genetic control and selection of breeding animals resistant to Scrapie would be the ideal solution. Moreover, recent studies on the potential impact of such breeding programmes applied in indigenous Chios breed sheep did not suggest any 
adverse effects on the animals' productive characteristics [22]. Unfortunately, in most farms the introduction of new animals is done without any preliminary screening or quarantine. In addition, there are usually no isolation facilities for peri-parturient animals. The prolonged latent period of Scrapie facilitates transmission from ewes to their offspring before neurological signs appear [21].

Lentivirus infections were documented both in sheep and goats in this study, although their incidence was considerably higher in the former species (Tables 1 and 2). Since their original diagnosis in Greece in 1967 [7], these infections are now endemic with several cases recorded per year. Lentivirus pathogenesis is poorly understood and infection persists, either active or in a carrier state, for life thus rendering affected small ruminants a constant source of infection for the entire flocks. Furthermore, the variability of host humoral immune response may produce confusing serodiagnostic results, with some animals taking several months to seroconvert. It is currently accepted that brain histopathology and immunohistochemistry are the optimal methods to diagnose this disease $[7,23,24]$. Due to the long latent infection period diagnosis is commonly set in adult animals, hence the impact on productivity and sustained economic losses are significant.

Listeriosis and polioencephalomalacia were the commonest neurological diseases in goats (Table 2). However, their occurrence in sheep was low. Small ruminants are more susceptible to listeriosis than cattle and sheep more resistant than goats [5,17]. Signs of focal encephalitis, especially affecting the brainstem, were the commonest clinical manifestation. In Greece, as well as in other countries, most cases are reported in goats during the winter months as a result of consuming poor quality silage (favouring Listeria growth) or rough browse like Quercus cocifera shrubs (favouring buccal mucosa abrasions and facilitating infection) [17].

Bacterial infection of CNS may be manifested as diffuse meningo-encephalitis or cerebrospinal abscess formation. Cerebral abscessation was observed in two adult goats showing ataxia and cortical blindness. Pyogenic microorganisms commonly incriminated include Actinomyces pseudotuberculosis, A. pyogenes, invading CNS either from adjacent infection sites (dehorning, caseous lymphadenitis) or hematogenously, in septicemic diseases $[5,17,24]$. In the present study the causative microorganisms were identified as Staphylococcus sp. Hematogenous infection may also cause diffuse meningoencephalitis. In small ruminants bacterial meningoencephalitis may be the complication of E.coli, Pasteurella spp., Streptococcus spp. or Mycoplasma spp. systemic infection (pneumonia, enteritis, mastitis), especially in immunocompromised animals (young lambs or kids deprived of colostrum intake) [5]. Bacterial meningoencephalitis was documented in one sheep and one goat flock, affecting young growing ( 8 months old) sheep in the former and adults in the latter.

Cerebral sarcocystosis, a protozoal encephalitis seen usually in young growing sheep, was documented histopathologically in two adult animals of the same flock. Most cases are diagnosed at post mortem examination, as the definite diagnosis of this 
disease in field conditions is very difficult [25]. Preventive measures, as applied in other protozoal infections (toxoplasmosis), are the only method for controlling this disease $[5,24]$.

Polioencephalomalacia, a metabolic disease of ruminants associated with the dysfunction of ATP-dependent sodium and potassium pump, usually affects young growing animals and less commonly adults [5]. Intracellular sodium accumulation ultimately leads to neuronal swelling, cytotoxic cerebral edema and pressure necrosis which primarily involve the gray matter [26,27]. The main predisposing factors are associated with sudden feeding changes, administration of poor quality or spoiled feedstuffs in combination with environmental stress factors (weaning) [5,14].

Metabolic and toxic disorders are a common cause of neurological dysfunction in small ruminants. In this report, rumen alkalosis was diagnosed as the cause of neurological signs in 2 sheep and 1 goat flock. Usually this abnormality is caused by feeding errors that disrupt the ruminal microflora by increasing its $\mathrm{pH}$. The ensuing failure of urea synthesis leads to excessive ammonia accumulation and toxic encephalopathy $[17,28]$.

Copper $(\mathrm{Cu})$ toxicity, manifested as hepatic encephalopathy, was diagnosed in one sheep flock. Toxic amounts of $\mathrm{Cu}$ were found in tissue samples from the liver, kidneys and brain of affected animals. Common causes of $\mathrm{Cu}$ poisoning in Greece include sheep grazing in pastures treated with $\mathrm{Cu}$ containing pesticides or feeding of concentrates formulated for administration in other animal species (usually pigs or poultry) [29,30].

Neurological signs attributed to pregnancy toxemia were noted in two sheep flocks. Both cases involved ewes carrying multiple fetuses in late pregnancy along with suboptimal energy feeding regimens. Negative energy balance and associated disruption of carbohydrate and lipid metabolism ultimately lead to hypoglycemic encephalopathy. Neurological dysfunction is caused both by hypoglycemia and hyperketonemia $[28,31,32]$. Typically, affected sheep developed anorexia, depression, seizures, cortical blindness and tetraparesis along with ketonuria $[31,33]$.

Enterotoxemia-associated neurologic dysfunction was diagnosed in three flocks. In two of those cases involved young (less than one month old) lambs and kids and concurrent coccidiosis could have contributed in the severity and extent of the problem. Proper vaccination solved the problem on a long term basis. Clostridium perfringens type $\mathrm{C}$ infection and associated $\mathrm{b}$ toxin production has been identified as the cause of neurologic signs. A proposed toxin patho-mechanism is the irreversible cell membrane depolarization [10,34]. Enterotoxemia is also associated with feeding errors in growing overfed small ruminants, as changes in the rumen microflora can occur. Its incidence in adult animals is considerably lower [34-36]. In Clostridium perfringens type $\mathrm{D}$ enterotoxemic encephalopathy focal encephalomalacia, microvascular damage and cerebral edema are the main histopathological findings [34].

Congenital malformations were reported in two sheep and one goat flocks. Sheep cases involved neonatal lambs presenting severe generalized ataxia caused by cerebellar hypoplasia. In both cases abnormally low vitamin A concentrations were documented 
in the serum of affected animals, although this hypovitaminosis has not been directly associated with cerebellar disease, rather than bone deformities and blindness [31]. Common causes of cerebellar hypoplasia in ruminants include viral infections of the developing fetus with Pestiviruses, Bluetongue and Schmallenberg viruses, as well as Toxoplasma gondii infection $[7,14]$. All the above factors were excluded in the presented cases.

Nervous system trauma was diagnosed in two sheep and one goat flocks. One ram and one adult female goat were examined with signs of thoracolumbar syndrome (T3-L3 lesion), that most likely had been caused by blunt spinal trauma. The third case involved an ewe that sustained bilateral sciatic nerve injury secondary to dystocia.

Conclusively, neurological diseases are an important part of small ruminant clinical practice, especially sheep. Chronic coenurosis, scrapie and OLE comprised the majority of ovine cases, while listeriosis, polioencephalomalacia and enterotoxemia were the commonest diagnoses in goats. The incidence and frequency in most of those disorders was directly related with poor flock management (husbandry, nutrition, preventive medicine among others), emphasizing its role in practice.

\section{Authors' contributions}

ZP and AP organized the data and wrote the manuscript. NG examined the animals and helped in writing. NP conducted necropsies and histopathology and helped in writing.

\section{Declaration of conflicting interests}

The author(s) declared no potential conflicts of interest with respect to the research, authorship, and/or publication of this article.

\section{REFERENCES}

1. Schenk HC, A Gerdwilker, M Ganter, W Baumgaertner, A Tipold: Clinical survey of neurological disease in small ruminants. J Vet Intern Med 2005, 19:293-294.

2. Giadinis ND, NK Panousis, ZS Polizopoulou, H Karatzias: Neurological examination of small ruminants. J Hellen Vet Med Soc 2006, 57:11-18.

3. Mayhew IG: Neurologic evaluation. In: Large animal neurology, a handbook for veterinary clinicians, 2nd ed. Wiley-Blackwell, 2009a, 11-56.

4. Constable PD: Clinical examination of the ruminant nervous system. Vet Clin North AmFood Anim Pract 2004, 20:185-214.

5. Machen MR, BM Waldridge, C Cebra, M Cebra, EB Belknap, LH Williamson, DG Pugh: Diseases of the neurologic system. In: Sheep and Goat Medicine. Saunders, 2002, 277-316. 
6. Eurostat: http://epp.eurostat.ec.europa.eu/portal/page/portal/eurostat/home, 2007. Accessed July 13th 2014.

7. Giadinis ND, ZS Polizopoulou, GC Fthenakis: Differential diagnosis of neurological diseases of small ruminants. J Hellen Vet Med Soc 2013, 64:275-296.

8. Skerritt GC. New diagnostic and operative approaches for gid. Proc Sheep Vet Soc 1987, 12:12-17.

9. Fragkiadaki EG, G Vaccari, LV Ekateriniadou, U Agrimi, ND Giadinis, B Chiappini, E Esposito, M Conte, R Nonno: PRNP genetic variability and molecular typing of natural goat scrapie isolates in a high number of infected flocks. Vet Res 2011, 42:104-110.

10. Pugh DG, A.N. Baird: Sheep and Goat Medicine, 2nd ed. Elsevier Saunders, 2011.

11. Kanata E, C Humphreys-Panagiotidis, ND Giadinis, N Papaioannou, M Arsenakis, T Sklaviadis: Perspectives of a scrapie resistance breeding scheme targeting Q211, S146 and K222 caprine PRNP alleles in Greek goats. Vet Res 2014, 45:43-48.

12. Komnenou A, S Argyroudis, N Giadinis, A Dessiris: Surgical treatment of coenurosis (gid) in sheep. Vet Rec 2000, 147:242-244.

13. Komnenou AT, S Argyroudis, ZS Polizopoulou, ND Giadinis, A Dessiris: Surgical treatment of coenurosis in sheep: a retrospective study and follow-up of 1,130 cases (1996-2004). J Vet Intern Med 2005, 19:285.

14. Scott PR: Other neurologic diseases. In: Diseases of Sheep, 4th ed. Blackwell Publishing, 2007, 259-270.

15. Taylor MA, RL Coop, RL Wall: Parasites of sheep and goats. In: Veterinary Parasitology. Blackwell Publishing, 2009.

16. Dyson DA, KA Linklater: Problems in the diagnosis of acute coenurosis in sheep. Vet Rec 1979, 104:528-529.

17. Smith MC, DM Sherman: Nervous system. In: Goat Medicine, 2nd ed. Wiley-Blackwell, 2009, 163-256.

18. Giadinis ND, V Psychas, ZS Polizopoulou, E Papadopoulos, N Papaioannou, AT Komnenou, AL Thomas, EJ Petridou, M Kritsepi-Konstantinou, SQ Lafi, GD Brellou: Acute coenurosis of dairy sheep from 11 flocks in Greece. N Z Vet J 2012, 60:247-253.

19. Papazachariadou M, A Founta, E Papadopoulos, S Chliounakis, K Antoniadou-Sotiriadou, Y Theodoridis: Gastrointestinal parasites of shepherd and hunting dogs in Serres prefecture. Vet Paras 2007, 148:170-173.

20. Tyler JW, JR Middleton: Transmissible spongiform encephalopathies in ruminants. Vet Clin North Am- Food Anim Pract 2004, 20:303-326.

21. Benestad SL, P Sarradin, B Thu, J Schoenheit, MA Tranulis, B Bratberg: Cases of scrapie with unusual features in Norway and designation of a new type Nor98. Vet Rec 2003, 153:202-208.

22. Psifidi A: PRNP genotyping of sheep using milk somatic cells and association of PRNP genotypes with animal traits. Doctoral thesis, Faculty of Veterinary Medicine, Aristotle University of Thessaloniki, Greece, 2010. http://invenio.lib.auth.gr/record/126222/files/ GRI-2011-6473. Accessed July 13th 2014.

23. Callan RJ, VC Van Metre: Viral diseases of the ruminant nervous system. Vet Clin North Am- Food Anim Pract 2004, 20:327-362.

24. Mayhew IG: Infectious, inflammatory and immune diseases. In: Large animal neurology, a handbook for veterinary clinicians, 2nd ed. Wiley-Blackwell, 2009b, 224-293. 
25. Caldow GL, JR Gildlow, A Schock: Clinical, pathological and epidemiological findings in three outbreaks of ovine protozoan myeloencephalitis. Vet Rec 2000, 146:7-10.

26. Cebra CK, ML Cebra: Altered mentation caused by polioencephalomalacia, hypernatremia and lead poisoning. Vet Clin North Am- Food Anim Pract 2004, 20:287-302.

27. Mayhew IG: Nutritional diseases. In: Large animal neurology, a handbook for veterinary clinicians, 2nd ed. Wiley-Blackwell, 2009c, 360-373.

28. Mayhew IG: Metabolic diseases. In: Large animal neurology, a handbook for veterinary clinicians, 2nd ed. Wiley-Blackwell, 2009d, 374-384.

29. Roubies N, ND Giadinis, ZS Polizopoulou, S Argyroudis: A retrospective study of chronic copper poisoning in 79 sheep flocks in Greece (1987-2007). J Vet Pharmacol Therap 2008, 31:181-183.

30. Giadinis ND, ZS Polizopoulou, N Roubies, H Karatzias: Presumed nephrogenic diabetes insipidus secondary to chronic copper hepatotoxicity in sheep. Vet Rec 2009, 166:433-434.

31. Mobini S, AM Heath, DG Pugh: Theriogenology of sheep and goats. In: Sheep and Goat Medicine. Saunders, 2002, 129-186.

32. Kabakci N, G Yarim, M Yarim, Ö Duru, BB Yagci, Ü Kisa: Pathological, clinical and biochemical investigation of naturally occurring pregnancy toxaemia of sheep. Acta VetBeograd 2003, 53, 161-169.

33. Sargison ND: Pregnancy toxaemia. In: Diseases of Sheep, 4th ed. Blackwell Publishing, 2007, 359-362.

34. Rings DM: Clostridial disease associated with neurologic signs: tetanus, botulism and enterotoxemia. Vet Clin North Am- Food Anim Pract 2004, 20:379-391.

35. Scholes SF, DB Welchman, JP Hutchison, DT Edwards, ES Mitchell: Clostridium perfringens type D enterotoxemia in neonatal lambs. Vet Rec 2007, 160:811-812.

36. Paez Lama S, D Grilli, V Egea, M Cerón Cucchi, M Fucili, L Allegretti, JC Guevara: Effect of the rearing system on the establishment of different functional groups of microorganisms in the rumen of kid goats. Acta Vet-Beograd 2015, 65, 175-190.

\section{NEUROLOŠKA OBOLJENJA MALIH PREŽIVARA U GRČKOJ: RETROSPEKTIVNA STUDIJA 114 STADA}

POLIZOPOULOU S Zoe, GIADINIS D Nektarios, PAPAHRISTOU Andreas, PAPAIOANNOU Nikolaos

Uprkos činjenici da neurološka oboljenja predstavljaju značajni deo interne medicine malih preživara, broj retrospektivnih studija njihove epizootiologije je do današnjeg dana ograničen. Ova studija prikazuje detaljan pregled epizootioloških podataka učestalosti neuroloških oboljenja ovaca i koza u Grčkoj. Studija je bazirana na podacima prikupljenim sa Klinike za farmske životinje, Fakulteta veterinarske medicine, A.U.Th od januara 2006. do maja 2011. Anamneza, rezultati kliničkih i neuroloških ispitivanja, kliničko-patološka i (ukoliko dostupna) patološka evaluacija su predstavljali minimum podataka koji su bili na raspolaganju. 
Bolesti nervnog sistema predstavljaju 37,9\% i 19,2\% od ukupnog broja ocenjenih slučajeva obolelih ovaca i koza. Najčešći neurološki poremećaji koji su dijagnostikovani kod ovaca su hronična cenuroza i skrepi, što čini $72 \%$ slučajeva, zatim manje uobičajena stanja, kao što su Lentivirusni encefalomijelitis koza (OLE), listerioza i akutna cenuroza. Kod koza učestalost različitih vrsta neuroloških bolesti je više ravnomerno raspoređena, dok su listerioza i polioencephalomalacia neurološke bolesti sa kojima smo se najčešće susretali. 